\title{
CHINA'S TRADE EFFICIENCY: MEASUREMENT AND DETERMINANTS
}

\section{PETER DRYSDALE, YIPING HUANG}

\section{AND K.P. KALIRAJAN}

China's open door policy has led to its increasingly deeper integration into the global economy during the reform period. Between 1978 and 1997, China's real GDP grew at an annual rate of 9.6 per cent. The average growth rate of trade was even higher, at 12.9 per cent, for the same period. According to the official statistics, China's export/GDP ratio increased from 9.1 per cent in 1978 to 25.6 per cent in 1997 (SSB 1997; APEG 1998). There is now consensus among economists that the official GDP data are under-estimated and that the per capita GNP in 1990 was about US\$1,000 instead of US\$370 (Garnaut and Ma 1993; Lardy 1994). According to these properly adjusted income data, China's current export-to-GDP ratio is slightly above 6 per cent. China still has great potential for export growth.

In what follows, the method used by Drysdale et al. (1998) to evaluate the efficiency of China's bilateral trade with individual countries will be applied. In a stochastic gravity model framework, trade efficiencies can be measured and their determinants identified. This will not only provide some idea about the efficiency performance of China's bilateral trade relative to other countries, but also suggest some policy measures to improve efficiency.

Bilateral trade flows have been the focus of an important part of the literature on international trade. In a comprehensive review of methodologies analysing bilateral trade flows in a many-country world, Drysdale and Garnaut (1982) identified two types of barriers (or resistances) to trade-objective and subjective resistances - and examined two analytical approaches - the gravity model and trade intensity analysis - which recur in this literature.

The gravity model, pioneered by Tinbergen (1962), offers a simple but useful framework for empirical studies identifying important factors influencing bilateral trade flows. In the studies by Tinbergen and many of his followers (such as 
Linnemann 1966), trade flows between two countries are determined by their respective gross national products and population, and resistance variables such as distance. Estimation of these conventional gravity models provides a picture of the average of the sample countries (Krugman 1991; Frankel 1993).

Assume a gravity model $X+f(T)$, where $X$ is China's bilateral trade flow and $T$ is a vector of explanatory variables. On a vertical axis $X$ and horizontal axis $T$, the conventionally estimated function can be expressed as a continuous curve $f(X)$ (Figure 15.1). Actual observations will be scattered around this curve. From estimation results, it can be predicted that if China's and the trade partner's explanatory variables are $T_{1}$, bilateral trade between China and that country is, on average, $X_{1}$.

The story at the average is important, but it does not reveal different performance across all observations. Even though the difference of a particular group of bilateral trade flows (such as trade among Asia Pacific economies) can be picked up by including additional dummy variables, comparison of individual performance is often impossible. In the real world, there are frequently observations with the same level of explanatory variables but vastly different trade flows (illustrated by points A and B in Figure 15.1).

The stochastic gravity model applied in this study generally follows the stochastic frontier approach that was first introduced by Aigner et al. (1977)

Figure 15.1 Conventional versus frontier gravity models

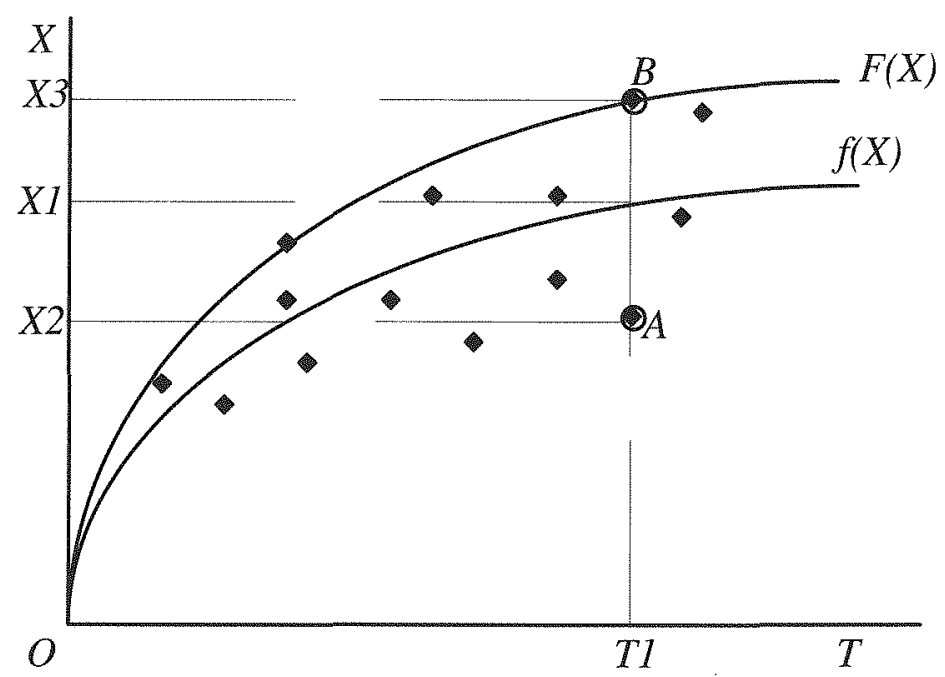

Notes: $X$ is China's bilateral trade flow. $T$ is a vector of explanatory variables. 
and Meeusen and van den Broeck (1977). ${ }^{`}$ Trade efficiency is defined as the ratio of actual to potential trade flow for each observation, following the popular idea of technical efficiency in production economics (Farrell 1957).

The Chinese case is examined in a broad data set for 57 countries for which data is available from the Australian National University's International Economic Databank. ${ }^{2}$ Variable averages of the 1991-95 period are used to avoid problems with yearly fluctuations.

\section{A STOCHASTIC GRAVITY MODEL}

The gravity model first applied by Tinbergen (1962) has the form ${ }^{3}$

$$
X_{i j}=\alpha_{0} G N P_{i}^{\alpha 1} G N P_{j}^{\alpha 2} D I S T_{i j}^{\alpha 3} D B^{\alpha 4} D P^{\alpha 5}
$$

where $X_{i j}$ is exports from country $i$ to country $j, G N P_{i}$ and $G N P_{j}$ are the GNP of exporting and importing countries, respectively, $D I S T_{i j}$ is the distance between country $i$ and country $j, D B$ is a dummy variable for adjacent countries and $D P$ is a dummy variable for common membership of a preferential tariff area.

Later empirical models all followed the spirit of the Tinbergen model, although there were important variations in terms of the functional forms and variables included. Linnemann (1966), for instance, introduced a complementarity variable, measured by the scalar product of the two vectors representing the commodity composition of the exporting country's total exports and the commodity composition of the importing country's total imports. Wolf and Weinchrott (1973) further expanded the model, following Tinbergen's notation

$$
X_{i j}=\alpha_{0} G N P_{i}^{\alpha 1} G N P_{j}^{\alpha 2} D I S T_{i j}^{\alpha 3} e^{\lambda C}+\phi S_{1}+\delta S_{2}+\rho S_{3}+u
$$

where $C$ are dummy variables relating to socio-cultural 'distance', $S_{1}$ is proxy for economic structure, $S_{2}$ is the relative per capita income, and $S_{3}$ is the relative ratio of per cent labour force in agriculture between country $i$ and country $j$.

An important feature of the conventional gravity model is its focus on the relationship at the average. In this study, we are more interested in determining the best performing frontier and the distance of individual observations from the frontier. Differing from Kalirajan (1999), the stochastic gravity model adopted here follows closely the model suggested by Aigner et al. (1977) and Meeusen and van den Broeck (1977) and draws on the procedures used to estimate stochastic frontier production functions in the literature (Coelli 1996). The major difference between the stochastic gravity model and the conventional gravity model described above is that the former has two error terms, one to account for trade inefficiency and the other to account for other factors such as measurement error in the trade variable. 
The stochastic gravity model can be defined as

$$
X_{i j}=f(T ; \beta) \exp \left(v_{i j}-u_{i j}\right)
$$

where $f(T ; \beta)$ is a suitable function of a vector $T$ (such as Cobb-Douglas functions in (1) and (2) above); $\beta$ is a vector parameter to be estimated; $v_{i j}$ is a random error having mean zero; and $u_{i j}$ is a non-negative random variable associated with the efficiency of trade between countries $i$ and $j$.

It is assumed that the random error, $v_{i j}$, is independently and identically distributed as a normal random variable with mean zero and variance $\sigma_{v}^{2}$. The random variable, $u_{i j}$, is assumed to have a half-normal distribution or exponential distribution.

In this model, the observed trade, $X_{i j}$, is bounded above by the stochastic quantity, $f(T ; \beta)+v_{i j}$, where $v_{i j}$ accounts for random variation of trade.

Given that the above stochastic gravity model is defined in terms of the logarithm of trade flows, the trade efficiency for export from country $i$ to $j$ is defined by

$$
T R E_{i j}=\exp \left[X_{i j}\right] / \exp \left[f(T ; \beta)+v_{i j}\right]^{\equiv \exp \left[-u_{i j}\right]}
$$

In empirical estimation, the computer package FRONTIER is used (Coelli 1996).

\section{DATA SET AND EMPIRICAL ESTIMATION}

The empirical study applies the following stochastic gravity model

$$
\begin{aligned}
& \ln X_{i j}=\beta_{0}+\beta_{1} \ln G D P_{i}+\beta_{2} \ln G D P_{j}+\beta_{3} \ln P O P_{i}+\beta_{4} \ln P O P_{j} \\
& \quad+\beta_{5} \ln D I S T_{i j}+\beta_{6} L A N G_{i j}+\beta_{7} C O M P_{i j}+\left(v_{i j}-u_{i j}\right)
\end{aligned}
$$

where $X_{i j}$ is export from country $i$ to country $j$; GDP and $P O P_{i}$ are exporting country's GDP and population, respectively; $G D P_{j}$ and $P O P_{j}$ are importing country's GDP and population, respectively; $D I S T_{i j}$ is the distance between exporting and importing countries; $L A N G_{i j}$ is a language dummy; and $C O M P_{i j}$ is an index of complementarity of resource endowment between the exporting and importing countries.

The data applied in this study is a cross-section data set containing 57 countries including China.

- Trade flows $\left(X_{i j}\right.$ ) are averages of exports from country $i$ to country $j$ between 1991 and 1995, measured in thousands of US dollars at 1993 prices. Trade data are compiled from the International Monetary Fund's Direction of Trade Statistics. 
- Gross domestic products $\left(G D P_{i}, G D P_{j}\right)$ are averages of GDP between 1991 and 1995, measured in thousands of US dollars at 1993 prices. GDP data are compiled from the World Bank's World Tables. Note that, following Garnaut and Ma (1993), GDP for China in 1990 was adjusted upward by a factor 2.5 and for the following years derived using this adjusted income and the official growth rate.

- Population $\left(P O P_{i}, P O P_{j}\right)$ are averages over the 1991-95 period, measured in persons. Population data are also compiled from the World Bank's World Tables.

- Distances $\left(D I S T_{i j}\right)$ are mostly geographical distances between the capital cities of the two countries, measured in kilometres. Distance data are taken from The Times Atlas of the World.

- The language variable ( $L A N G_{i j}$ ) is a dummy. It takes the value of 1 if the exporting and importing countries share the same language, and equals 0 otherwise.

- An index of complementarity of resources $\left(C O M P_{i j}\right)$ is constructed by the authors to reflect the role of relative factor endowments in encouraging or inhibiting trade flows between trading countries. A comprehensive study of factor endowments and trade patterns by Song (1996) reports quantities of various factors for individual countries. These are first aggregated into four types of resources: capital, labour, land and minerals. Next, taking world average of each factor as 100 , indexes for each type of factor for each country are constructed. Finally, an index of complementarity of resource endowment is defined by

$$
C O M P_{i j}=\frac{1}{\sum_{k=1}^{4}\left[S_{i j}^{k} *\left(F_{i}^{k} / \sum_{m=1}^{4} F_{i}^{m}\right) *\left(F_{j}^{k} / \sum_{m=1}^{4} F_{j}^{m}\right)\right]}
$$

where $S_{i j}^{k}$ is the share of $k$-intensive products in total exports from country $i$ to country $j, F_{i}^{k}$ and $F_{j}^{k}$ are indexes (relative to the world average, 100) of factor endowments in exporting and importing countries. It is obvious that if both countries are abundant in one type of resource, such as labour, and scarce in others, and if labour-intensive products are a dominant trade commodity, then a high number can be expected in the denominator. This implies a small overall number; that is, resource endowments in the two countries are not complementary with each other.

The estimation results using the above data set are presented in Table 15.1. The second column gives the results of the conventional gravity model applying the ordinary least squares (OLS) approach and the third column shows the stochastic gravity model applying the maximum likelihood estimation method. 
In both models, parameter estimates are all significant (except $C O M P_{i j}$ in the stochastic gravity model) with the expected signs.

\section{TRADE EFFICIENCY AND ITS DETERMINANTS}

Based on the estimation results and the definition of trade efficiency (4), we can derive trade efficiency $\left(T R E_{i j}\right)$ for each bilateral trade flow (Table 15.2). There are two types of average for each country: one with the reporting country as an exporter and another with the reporting country as an importer. The average trade efficiency of the 57 countries was 0.34 . In other words, the sample countries only achieved a third of the best performance observed in international trade in this period.

Table 15.1 Estimation of the gravity model

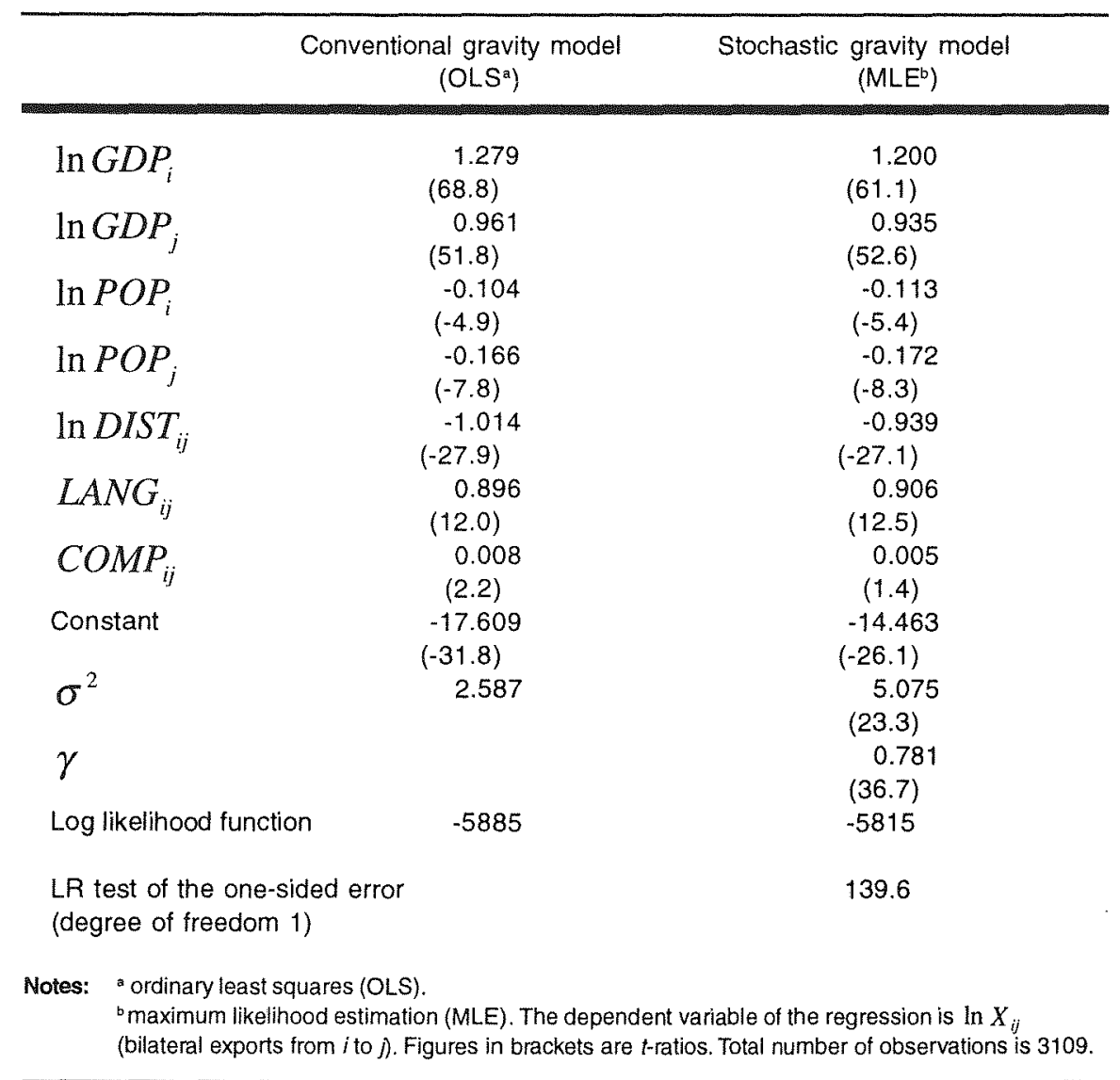


It is interesting to note that Asian countries-such as China, Hong Kong, Indonesia, Korea, Malaysia, Singapore, Taiwan and Thailand-performed quite well in terms of trade efficiency. Some of the European countries also did well, including Belgium-Luxembourg, Finland, Ireland, Netherlands, Sweden and Switzerland. Surprisingly, trade efficiency for both Japan and the United States (except as an importer) were below the sample average. One explanation is that trade elasticity with respect to GDP is not constant, as large countries usually have lower trade dependency ratios.

Table 15.2 Average trade efficiency indexes for sample countries

\begin{tabular}{|c|c|c|c|c|c|}
\hline $\begin{array}{l}\text { Reporting } \\
\text { country }\end{array}$ & $\begin{array}{c}\text { As } \\
\text { exporter }\end{array}$ & $\begin{array}{c}\text { As } \\
\text { importer }\end{array}$ & $\begin{array}{l}\text { Reporting } \\
\text { country }\end{array}$ & $\begin{array}{c}\text { As } \\
\text { exporter }\end{array}$ & $\begin{array}{c}\text { As } \\
\text { importer }\end{array}$ \\
\hline Argentina & 0.30 & 0.24 & Jamaica & 0.23 & 0.33 \\
\hline Australia & 0.30 & 0.31 & Japan & 0.31 & 0.33 \\
\hline Austria & 0.27 & 0.22 & Korea, Rep. of & 0.49 & 0.39 \\
\hline Belgium-Luxem. & 0.43 & 0.46 & Malaysia & 0.54 & 0.40 \\
\hline Brazil & 0.38 & 0.31 & Malta & 0.35 & 0.34 \\
\hline Canada & 0.26 & 0.32 & Mauritius & 0.33 & 0.36 \\
\hline Chile & 0.46 & 0.40 & Mexico & 0.23 & 0.30 \\
\hline China & 0.28 & 0.27 & Netherlands & 0.41 & 0.49 \\
\hline Colombia & 0.35 & 0.31 & New Zealand & 0.45 & 0.31 \\
\hline Costa Rica & 0.40 & 0.35 & Nicaragua & 0.33 & 0.34 \\
\hline Cyprus & 0.21 & 0.38 & Norway & 0.35 & 0.28 \\
\hline Denmark & 0.38 & 0.29 & Panama & 0.20 & 0.47 \\
\hline Dominican Rep. & 0.23 & 0.35 & Paraguay & 0.29 & 0.29 \\
\hline Ecuador & 0.37 & 0.33 & Peru & 0.30 & 0.29 \\
\hline Egypt & 0.22 & 0.39 & Philippines & 0.32 & 0.34 \\
\hline El Salvador & 0.20 & 0.32 & Portugal & 0.30 & 0.37 \\
\hline Finland & 0.42 & 0.31 & Singapore & 0.60 & 0.48 \\
\hline France & 0.30 & 0.35 & Spain & 0.29 & 0.36 \\
\hline Germany & 0.29 & 0.39 & Sri Lanka & 0.44 & 0.37 \\
\hline Ghana & 0.31 & 0.32 & Sweden & 0.40 & 0.33 \\
\hline Greece & 0.26 & 0.32 & Switzerland & 0.40 & 0.31 \\
\hline Honduras & 0.29 & 0.37 & Taiwan & 0.52 & 0.41 \\
\hline Hong Kong & 0.39 & 0.46 & Thailand & 0.47 & 0.41 \\
\hline Iceland & 0.28 & 0.18 & Turkey & 0.26 & 0.29 \\
\hline India & 0.29 & 0.27 & United Kingdom & 0.32 & 0.40 \\
\hline Indonesia & 0.43 & 0.33 & Uruguay & 0.38 & 0.37 \\
\hline Ireland & 0.45 & 0.29 & USA & 0.23 & 0.36 \\
\hline Israel & 0.36 & 0.30 & Venezuela & 0.32 & 0.31 \\
\hline Italy & 0.34 & 0.37 & Average & 0.34 & 0.34 \\
\hline
\end{tabular}


Trade efficiency for China's bilateral trade with 56 countries in the sample was also determined (Table 15.3). The average efficiency index was 0.28 when China was the exporter and 0.27 when China was the importer, both substantially lower than the sample average.

It would be inappropriate to draw any direct implications from examination of individual indices, but it can be noted that, in general, China's efficiency was higher for trade with other APEC economies - especially Chile, Hong Kong, Indonesia, Malaysia, Singapore and Thailand. Taiwan was an exception with which China still did not have direct trade relations. On average, trade efficiency with the APEC economies (excluding Taiwan) was 0.35 for China as an exporter and 0.42 for China as an importer. It must be noted that this efficiency measure

Table 15.3 Bilateral trade efficiency indexes for China

\begin{tabular}{|c|c|c|c|c|c|}
\hline $\begin{array}{l}\text { Partner } \\
\text { country }\end{array}$ & $\begin{array}{l}\text { China as } \\
\text { exporter }\end{array}$ & $\begin{array}{l}\text { China as } \\
\text { importer }\end{array}$ & $\begin{array}{l}\text { Partner } \\
\text { country }\end{array}$ & $\begin{array}{l}\text { China as } \\
\text { exporter }\end{array}$ & $\begin{array}{l}\text { China as } \\
\text { importer }\end{array}$ \\
\hline Argentina & 0.25 & 0.36 & Jamaica & 0.34 & 0.20 \\
\hline Australia & 0.34 & 0.48 & Japan & 0.25 & 0.21 \\
\hline Austria & 0.09 & 0.29 & Korea, Rep. of & 0.20 & 0.31 \\
\hline Belgium-Luxembourg & 0.28 & 0.39 & Malaysia & 0.46 & 0.63 \\
\hline Brazil & 0.23 & 0.42 & Malta & 0.24 & 0.06 \\
\hline Canada & 0.29 & 0.43 & Mauritius & 0.37 & 0.04 \\
\hline Chile & 0.44 & 0.55 & Mexico & 0.17 & 0.07 \\
\hline Colombia & 0.15 & 0.16 & Netherlands & 0.37 & 0.26 \\
\hline Costa Rica & 0.22 & 0.43 & New Zealand & 0.29 & 0.54 \\
\hline Cyprus & 0.27 & 0.03 & Nicaragua & 0.18 & 0.01 \\
\hline Denmark & 0.17 & 0.23 & Norway & 0.12 & 0.24 \\
\hline Dominican Rep. & 0.33 & 0.00 & Panama & 0.66 & 0.01 \\
\hline Ecuador & 0.31 & 0.30 & Paraguay & 0.45 & 0.14 \\
\hline Egypt & 0.43 & 0.14 & Peru & 0.29 & 0.60 \\
\hline El Salvador & 0.31 & 0.12 & Philippines & 0.36 & 0.36 \\
\hline Finland & 0.13 & 0.40 & Portugal & 0.14 & 0.14 \\
\hline France & 0.20 & 0.27 & Singapore & 0.43 & 0.53 \\
\hline Germany, Unified & 0.30 & 0.35 & Spain & 0.21 & 0.26 \\
\hline Ghana & 0.42 & 0.42 & Sri Lanka & 0.45 & 0.13 \\
\hline Greece & 0.17 & 0.12 & Sweden & 0.18 & 0.38 \\
\hline Honduras & 0.40 & 0.00 & Switzerland & 0.14 & 0.33 \\
\hline Hong Kong & 0.59 & 0.54 & Taiwan & 0.14 & 0.03 \\
\hline Iceland & 0.04 & 0.06 & Thailand & 0.39 & 0.46 \\
\hline India & 0.19 & 0.17 & Turkey & 0.18 & 0.30 \\
\hline Indonesia & 0.42 & 0.57 & United Kingdom & 0.28 & 0.23 \\
\hline Ireland & 0.14 & 0.17 & Uruguay & 0.39 & 0.68 \\
\hline Israel & 0.13 & 0.20 & USA & 0.32 & 0.23 \\
\hline Italy & 0.22 & 0.31 & Venezuela & 0.21 & 0.06 \\
\hline
\end{tabular}


has already controlled for impact of the common factors affecting bilateral trade including population, income and distances.

What are the factors determining trade efficiency? In this study, two types of policy variable are considered. The first is policies adopted by governments themselves and the second is regional agreements between governments. To identify the important policy factors influencing efficiency for the whole sample, the following linear function is adopted

$$
\begin{gathered}
T R E_{i j}=\lambda_{0}+\lambda_{1} T A X_{i}+\lambda_{2} F D_{i}+\lambda_{3} T_{A X}+\lambda_{4} F D_{j}+\pi_{1} E U+\pi_{2} \text { APEC } \\
+\pi_{3} C E R+\pi_{4} A S E A N+\pi_{5} \text { NAFTA }+\pi_{6} \text { ANDEAN }+\pi_{7} \text { MERCOSUR }
\end{gathered}
$$

where $T A X_{i}$ and $T A X_{j}$ are, respectively, the average tariff or tax rate on both imports and exports in the two countries for the 1990-95 period. The tax rates are drawn from the Fraser Institute in Vancouver and are expressed in percentage form (Gwartney and Lawson 1997). $F D_{i}$ and $F D_{j}$ are indexes of economic freedom in 1995 which range from 0 (no freedom) to 10 (complete freedom). The freedom indexes were constructed by the Fraser Institute and aggregated over more than a dozen freedom indicators covering macroeconomic stability, the role of government and corporate sector in business, price flexibility, legal system and policies regarding foreign investment and international trade (Gwartney and Lawson 1997). The rest of the variables included in (7) (EU, $A P E C, C E R, A S E A N, N A F T A, A N D E A N$ and MERCOSUR) are dummies for common membership of regional agreements.

To see if determination of China's trade efficiency was different from the whole sample, equation (7) is re-estimated using only observations with China as one of the trade partners (a total of 112 observations) (Table 15.4). All the dummy variables for regional blocs, except that for APEC, are omitted from the equation as China is not a member of any of them.

Equation (7) is first estimated using the OLS approach. However, both the Breusch-Pagan-Godfrey test and the Glejser test suggest that the equations using the OLS approach suffer from a heteroscedasticity problem. ${ }^{4}$ The model is thus re-estimated applying the White-heteroscedasticity consistent estimation approach (White 1993). And these re-estimated results are the focus of interpretation (columns 2 and 4 of Table 15.4).

For the results using the whole sample (column 2), the trade tariff/taxes in both exporting and importing countries are found to be insignificant. However, the overall economic freedom index in both countries is very important in determining trade efficiency. The freer the overall economic system, the higher the efficiency in bilateral trade. The strange results on trade taxes may be due to the fact that the freedom indexes already incorporate trade taxes (Gwartney and Lawson 1997). 
Table 15.4 Determinants of trade efficiency

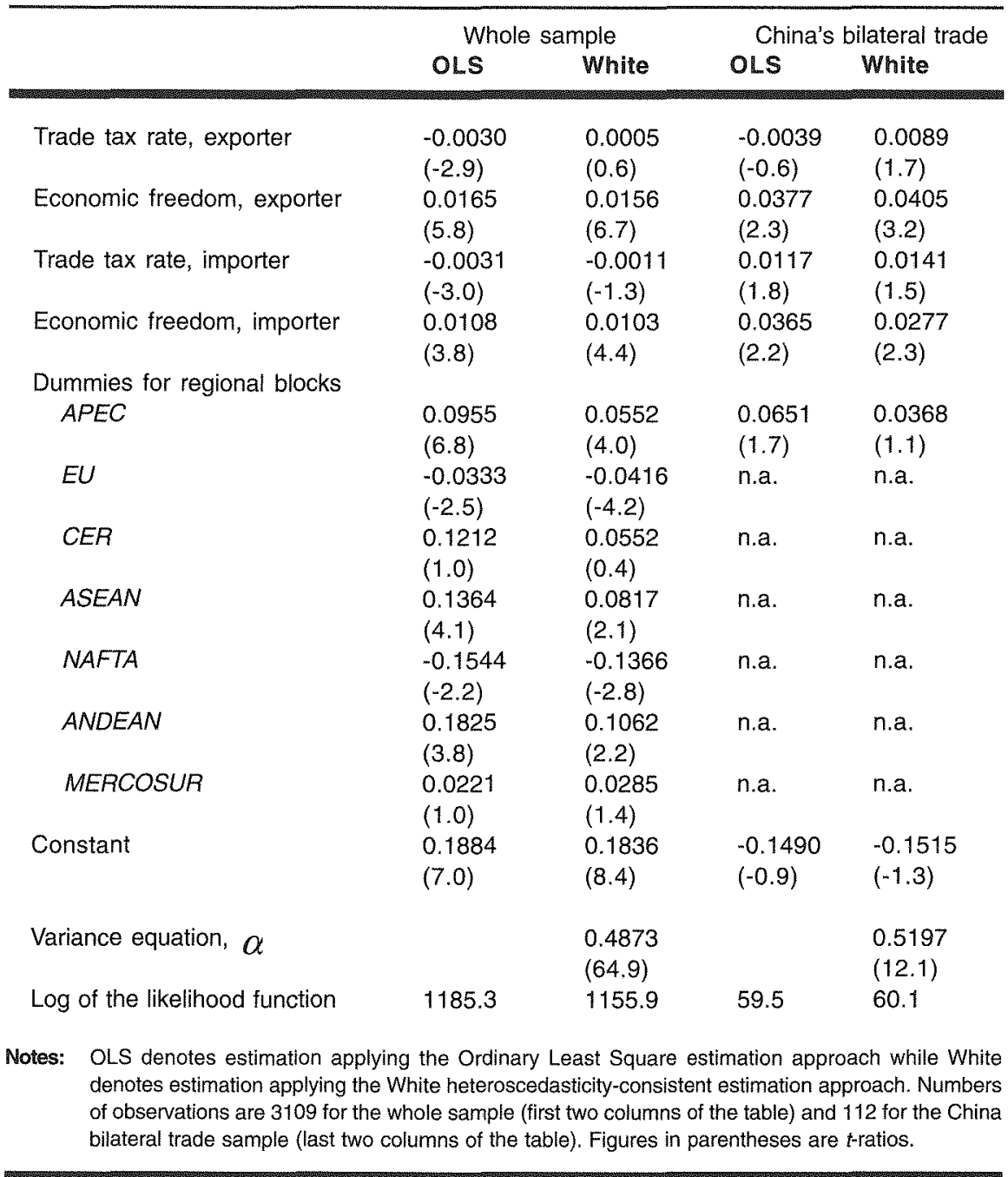

While CER and MERCOSUR did not seem to play any significant role independently of other determinants of bilateral trade efficiency, the impact of both $E U$ and NAFTA are surprisingly negative. The formation of $A P E C, A S E A N$ and $A N D E A N$ helped to improve trade efficiency among member countries.

The results using only the China sub-sample (column 4) reveal similar information. Coefficients for freedom variables in both exporting and importing countries are positive and significant, and trade taxes in both exporting and 
importing countries are insignificant in determining bilateral trade efficiency. The only exception is that the coefficient estimate for APEC is not significant in the China equation, suggesting that China's higher trade efficiency with APEC economies revealed earlier is mainly determined by the freedom variables in both China and its trade partner economies.

\section{CONCLUSIONS}

This chapter has focused on trade efficiency in China's bilateral trade and its determinants in the context of a multi-country world. The stochastic gravity model approach was applied to a cross-section bilateral trade data set containing 57 countries using the average trade flows and other variable values for the period 1991-95 (a total of 3109 observations). Trade efficiency indexes were calculated for each pair of trading countries. Finally, an effort was made to identify the policy determinants of trade efficiency. An equation was estimated separately to examine specifically the mechanism determining efficiency in China's bilateral trade.

Average trade efficiency for China was not only lower than that for the East Asian economies as a group but also below the average of the whole sample. Thus the potential for China to improve trade efficiency and further expand both exports and imports is huge.

The implication from the exercise of identifying efficiency determinants is that inefficiency may partly be removed through appropriate policy reform. For China, an increase in overall economic freedom - which includes a lower level of trade taxes - is helpful to improvement in trade efficiency. A freer economic environment in China's trade partners is also favourable for higher trade efficiency for China.

\section{REEERENCES}

Aigner, D.J., Lovell, C.A.K. and Schmidt, P., 1977. 'Formulation and estimation of stochastic frontier production function models', Journal of Econometrics, $6: 21-37$.

Asia Pacific Economics Group (APEG), 1998. Asia Pacific Profiles, Financial Times (Finance), Hong Kong.

Breusch, T.S. and Pagan, A.R., 1979. 'A simple test for heteroscedasticity and random coefficient variation', Econometrica, 47:1278-94.

Coelli, T., 1996. 'A Guide to FRONTIER version 4.1: a computer program for stochastic frontier production and cost function estimation', Working Paper 96/07, Centre for Efficiency and Productivity Analysis, University of New England, Armidale. 
Drysdale, P. and Garnaut, R., 1982. 'Trade intensities and the analysis of bilateral trade flows in a many-country world: a survey', Hitotsubashi Journal of Economics, 22(2):62-84.

Drysdale, P., Huang, Y. and Kalirajan, K.P., 1998. 'Measuring and explaining trade efficiency', seminar paper presented at the Asia Pacific Economies Program seminar, Asia Pacific School of Economics and Management, The Australian National University, Canberra, August 1998.

Farrell, M.J., 1957. 'The measurement of productive efficiency', Journal of the Royal Statistical Society, Series A, 120:253-81.

Frankel, J.A., 1993. 'Is Japan creating a yen bloc in East Asia and the Pacific?', in J.A. Frankel and M. Kahler (eds), Regionalism and Rivalry: Japan and the United States in Pacific Asia, University of Chicago Press, Chicago.

Garnaut, R. and Ma, G., 1993. 'How rich is China: evidence from the food economy', Australian Journal of Chinese Affairs, (30):121-46.

Gwartney, J.D and Lawson, R.A., 1997. Economic Freedom of the World: 1997 Annual Report, The Fraser Institute, Vancouver.

Kalirajan, K., 1999. 'Stochastic varying coefficients gravity model: an application in trade analysis', Journal of Applied Statistics, 26(2):185-94.

Kalirajan, K.P. and Shand, R.T., 1994. Economics in Disequilibrium: an approach from the frontier, Macmillan, New Delhi.

Krugman, P., 1991. 'The move toward free trade zones', in Policy implication of trade and currency zones, Federal Reserve Bank of Kansas, Jackson Hole, Wyoming, August.

Lardy, N., 1994. China and the World Economy, The Institute of International Economics, Washington, DC.

Linnemann, H., 1966. An Econometric Study of World Trade Flows, NorthHolland, Amsterdam.

Meeusen, W. and van den Broeck, J., 1977. 'Efficiency estimation from Cobb Douglas production function with composed error', Intermational Economic Review, 18:435-44.

Polak, J.J., 1996. 'Is APEC a natural regional trading bloc? a critique of the Gravity Model of international trade', World Economy, 19(5):533-43.

Song, L., 1996. Changing Global Comparative Advantage: evidence from Asia and the Pacific, Addison-Wesley, Sydney.

Tinbergen, J., 1962. Shaping the World Economy-suggestions for an international economic policy, Twentieth Century Fund, New York.

White, J., 1993. SHAZAM Econometric Computer Program: User's Reference Manual Version 7.0, McGraw-Hill Book Company, New York. 
Wolf, C. Jr. and Weinchrott, D., 1973. 'International transactions and regionalism: distinguishing 'insiders' from 'outsiders", American Economic Review, 63(2):52-60.

Yun, S. and Sen, A., 1994. 'Computation of maximum likelihood estimates of Gravity Model parameters', Journal of Regional Science, 34(2):199-216.

\section{NOTES}

We are grateful for valuable comments and suggestions by Ray Trewin, William Griffiths, Ligang Song and participants of the 26th Conference of Economists of Australia, a seminar at the Australian National University and the workshop on APEC and China at the Chinese Academy of Social Sciences in Beijing. Special thanks are also due to Ligang Song and Xinpeng Xu for assistance on the data set.

1 For a review of the literature on frontier production functions, see Kalirajan and Shand (1994).

2 The sections on methodology and the econometric results for the whole sample were drawn from Drysdale et al. (1998).

3 For a review of the literature on the gravity model, see Drysdale and Garnaut (1982).

4 The B-P-G test statistic is 100.9 and the Glejser test statistic is 95.72 , with 11 degrees of freedom. Both are far above the $\chi^{2}$ critical value at 5 per cent significance level (19.68). The test results for the China sub-sample are basically the same. 